\title{
Analisa Perbandingan Citra Hasil Segmentasi Menggunakan Metode K-Means dan Fuzzy C Means pada Citra Input Terkompresi
}

\author{
I Wayan Angga Wijaya Kusuma ${ }^{1)}$, dan Afriliana Kusumadewi ${ }^{2)}$ \\ ${ }^{1,2)}$ Fakultas Teknik, Program Studi Teknik Elektro, Universitas Widya Dharma \\ 1,2) Jl. Ki Hajar Dewantara, Desa Karanganom, Kecamatan Klaten Utara, Kabupaten Klaten \\ e-mail: anggaelectro@yahoo.com ${ }^{1)}$, lina@ unwidha.ac.id ${ }^{2)}$
}

\begin{abstract}
In pattern recognition, image processing plays a role in automatically separating objects from the background. In addition, the object will be processed by the pattern classifier. In the medical world, image processing plays a very important role. CT Scan (Computed Tomography) or CAT Scan (Computed Axial Tomography) is an example of an image processing application that can be used to view fragments or cross sections of parts of the human body. Tomography is the process of producing twodimensional images from three-dimensional film through several one-dimensional scans. Magnetic resonance imaging (MRI) is the image most often used in the field of radiology. MRI images can display the anatomical details of objects clearly in multiple sections (multiplanar) without changing the patient's position. In this study, two methods were compared, namely $\mathrm{K}$ Means and Fuzzy C Means, in a segmentation process with the aim of separating between normal areas or areas with disturbances (lesions). The images used are brain and chest MRI images with a total of 10 MRI images. The image quality of the segmentation results is compared with the quality test using the Variation of Information (VOI) parameters, Global Consistency Error (GCE), MSE (Mean Square Error), PSNR (Peak Signal to Noise Ratio) and segmentation time.
\end{abstract}

Keywords: medical, pattern processing, segmentation, $k$-means, fuzzy c means

\section{ABSTRAK}

Dalam pengenalan pola, pemrosesan gambar berperan dalam memisahkan objek secara otomatis dari latar belakang. Selain itu, objek akan diproses oleh pengklasifikasi pola. Dalam dunia medis, pengolahan citra memegang peranan yang sangat penting. CT Scan (Computed Tomography) atau CAT Scan (Computed Axial Tomography) adalah contoh aplikasi pemrosesan gambar yang dapat digunakan untuk melihat fragmen atau penampang melintang dari bagian tubuh manusia. Tomografi adalah proses menghasilkan gambar dua dimensi dari film tiga dimensi melalui beberapa pemindaian satu dimensi. Magnetic resonance imaging (MRI) adalah teknik pencitraan yang paling umum digunakan dalam radiologi. Gambar MRI dapat dengan jelas menunjukkan detail anatomi objek di bagian yang berbeda (multiplanar) tanpa mengubah posisi pasien. Pada penelitian ini membandingkan dua metode yaitu K-Means dan Fuzzy C Means adalah proses segmentasi dengan tujuan memisahkan antara area normal ataupun area yang mengalami gangguan (lesi). Citra yang digunakan adalah citra MRI otak dan dada dengan total 10 citra MRI. Kualitas citra hasil segmentasi dibandingkan dengan uji kualitas menggunakan parameter Variation of Information (VOI), Global Consistency Error (GCE), MSE (Mean Square Error), PSNR (Peak Signal to Noise Ratio) dan waktu segmentasi.

Kata kunci: medis, pengolahan pola, segmentasi, k-means, fuzzy c means

\section{Pendahuluan}

$\mathrm{P}$ emrosesan citra adalah bagian penting dari fondasi berbagai aplikasi praktis, seperti pengenalan pola, penginderaan jauh melalui satelit atau pesawat, dan penglihatan mesin. Dalam pengenalan pola, pemrosesan gambar berperan dalam memisahkan objek secara otomatis dari latar belakang. Selain itu, objek akan diproses oleh pengklasifikasian pola.

Aplikasi pemrosesan gambar menjadi lebih luas. Dalam dunia medis, pengolahan citra memegang peranan yang sangat penting. CT scan (computed tomography scan) atau kadang disebut CAT scan (computed axial tomography scan) adalah contoh aplikasi pemrosesan gambar yang dapat digunakan untuk melihat fragmen atau penampang bagian tubuh manusia. Tomografi adalah proses menghasilkan gambar dua dimensi dari film tiga dimensi melalui beberapa pemindaian satu dimensi.

Berikutnya aplikasi pengolahan citra adalah Magnetic resonance imaging (MRI) adalah gambar yang paling banyak digunakan dalam radiologi [1]. Gambar MRI dapat dengan jelas menunjukkan objek anatomi rinci di bagian yang berbeda tanpa memposisikan ulang pasien. Beberapa masalah umum dengan gambar medis adalah hasil pemindaian yang buruk karena noise figure. Kualitas gambar medis juga disebabkan oleh noise acak dengan distribusi kasar, intensitas tidak merata yang mengarah pada artefak dan efek volume parsial. Mengingat masalah ini, sulit bagi dokter dan peneliti untuk menganalisis diagnosis kelainan pasien. Oleh karena itu, ada kebutuhan untuk meningkatkan kualitas gambar MRI medis dengan tujuan menghasilkan gambar dengan kualitas yang jauh lebih tinggi daripada gambar aslinya. Penelitian ini membandingkan dua metode yaitu K-Means dan Fuzzy CMeans. Ini adalah proses segmentasi yang bertujuan untuk mengisolasi area yang normal atau memiliki lesi. Gambar yang digunakan adalah gambar MRI otak dan dada, total ada 10 gambar MRI. Kualitas gambar tersegmentasi dibandingkan dengan uji kualitas menggunakan parameter variasi informasi (VOI), kesalahan integritas global (GCE), kesalahan rata-rata kuadrat (MSE), rasio signal-to-noise maksimum (PSNR) dan segmentasi waktu. 


\section{TEORI}

Segmentasi citra menggunakan algoritma K-Means, termasuk penelitian oleh Nurhasanah [1] yang mengusulkan pemetaan putih, abu-abu, dan CSF dalam segmen citra MRI menggunakan teknik clustering KMeans. Banyak penelitian telah dilakukan pada. Algoritma k-means clustering dipilih karena sederhana dan mudah diimplementasikan serta dapat menangani data anomali.

Penelitian selanjutnya oleh Jipkate dan Gohokar [2] membandingkan algoritma segmentasi citra K-Means dengan fuzzy clustering c-Means. Analisis dan perbandingan algoritma yang dikembangkan oleh MATLAB. K-means clustering menghasilkan tingkat akurasi yang tinggi dan membutuhkan waktu komputasi yang relatif singkat. Fuzzy c-means memberikan hasil yang lebih baik daripada k-means, namun membutuhkan waktu komputasi yang lebih lama dibandingkan kmeans karena algoritmanya menyertakan langkahlangkah perhitungan fuzzy.

Studi lain [3] yang dilakukan oleh Samma dan Salam menyarankan segmentasi citra berdasarkan algoritma clustering K-Means adaptif. Metode yang diusulkan mencoba untuk mengembangkan algoritma K-Means untuk mencapai kinerja dan efisiensi yang tinggi. Selain itu, ini memecahkan beberapa masalah pemilihan model dengan menentukan jumlah cluster menggunakan kumpulan gambar yang disumbangkan dengan nilai absolut antara ukuran bingkai dan kepentingan dan menambahkan metrik lainnya. Transfer pengukuran.

Penelitian lebih lanjut dilakukan oleh Preeti Panwar, Girdhar Gopal dan Rakesh Kumar [4]. Para peneliti membandingkan segmentasi berbasis warna dengan kmeans clustering dan algoritma threshold. Metode cluster k-means menggunakan metode partisi. Algoritma kmeans clustering digunakan untuk membagi citra menjadi k cluster. Dalam penelitian ini, kami menggunakan K-Means Pooling dan Threshold Processing untuk membandingkan hasil segmentasi. Perbandingan kedua teknologi ini didasarkan pada parameter segmentasi seperti MSE, PSNR dan NSR. MSE dan PSNR dapat digunakan secara luas untuk mengukur tingkat distorsi gambar karena dapat mewakili tingkat total kesalahan skala abu-abu di seluruh gambar.

Dengan dua teknik ini, Anda dapat menggunakan parameter seperti MSE, PSNR, dan SNR untuk lebih membagi lagi performa gambar yang berbeda. Dari pengamatan yang disajikan dalam penelitian ini, kita dapat menyimpulkan bahwa teknik ambang memberikan output dua tingkat. Namun, dengan metode kmeans, keluaran setiap segmen sama dengan ukuran cluster. Kelompok kinerja tumbuh dengan ukuran. Faktor lain dalam ukuran cluster adalah persentase akurasi. Gunakan UMK dan PSNR untuk mengukur kualitas rekonstruksi. Nilai PSNR keempat gambar di K-Means pool lebih tinggi dari gambar aslinya, dan nilai MSE lebih kecil.

\section{A. Citra Digital}

Citra digital terdiri dari sekumpulan titik yang disebut piksel. Setiap piksel diwakili oleh kotak kecil. Setiap piksel memiliki koordinat posisi [5]. Sistem koordinat yang digunakan untuk merepresentasikan citra digital ditunjukkan pada Gambar 1.

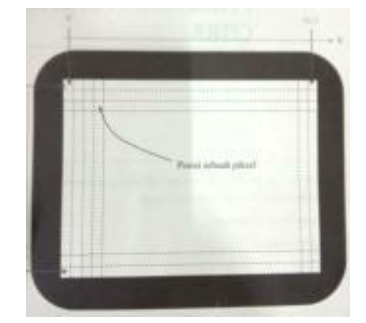

Gambar 1. Sistem koordinat citra berukuran M x N (M baris dan N baris)

Dengan sistem koordinat yang mengikuti prinsip pemindaian pada layar televisi standar, sebuah piksel memiliki koordinat dalam bentuk (x,y). Dalam hal itu:

- x mewakili posisi kolom;

- y mewakili posisi garis;

- piksel di sudut kiri atas memiliki koordinat $(0,0)$ dan piksel di sudut kanan bawah memiliki koordinat (N-1, M-1).

\section{B. Citra Berwarna}

Citra berwarna atau yang biasa disebut dengan citra RGB adalah jenis citra yang merepresentasikan warna dalam bentuk komponen R (merah), G (hijau), dan B (biru). Setiap komponen warna menggunakan 8 bit (rentang nilai 0-255). Oleh karena itu, warna yang dapat ditampilkan mencapai 255 x 255 x 255 atau 16.581 .375 warna. Tabel 1 menunjukkan contoh warna dan nilai RGB.

\begin{tabular}{cccc}
\multicolumn{4}{c}{ Tabel 1. Warna dan nilai penyusunan warna } \\
\hline Warna & $\mathrm{R}$ & $\mathrm{G}$ & $\mathrm{B}$ \\
\hline Merah & 255 & 0 & 0 \\
\hline Hijau & 0 & 255 & 0 \\
\hline Biru & 0 & 0 & 255 \\
\hline Hitam & 0 & 0 & 0 \\
\hline Putih & 255 & 255 & 255 \\
\hline Kuning & 0 & 255 & 255 \\
\hline
\end{tabular}

\section{Citra Berskala Keabuan}

Seperti namanya, pengolahan citra jenis ini merupakan gradien hitam putih yang tentunya akan menghasilkan rona abu-abu [5]. Dalam gambar seperti itu, warna ditunjukkan dengan intensitas. Dalam kasus ini, rentang intensitasnya adalah 0 hingga 255 . Nilai 0 berarti hitam, dan nilai 255 berarti putih.

\section{Citra Biner}

Gambar biner adalah gambar di mana setiap piksel diwakili oleh hanya dua nilai yang mungkin (yaitu, nilai 0 dan 1) [5]. Nilai 0 berarti hitam, dan nilai 1 berarti putih. Citra jenis ini banyak digunakan dalam pengolahan citra, misalnya untuk mendapatkan keunggulan 
obyek tepi. Gambar 2 menunjukkan gambar dengan corak abu-abu dan mengubah gambar yang diubah menjadi gambar biner.

Faktanya, karena banyak pemrosesan gambar dilakukan dalam skala abu-abu, biasanya gambar berwarna perlu diubah menjadi gambar skala abu-abu. Namun, terkadang gambar grayscale perlu diubah menjadi gambar biner, karena beberapa operasi dalam pemrosesan tersebut dijalankan pada gambar biner.

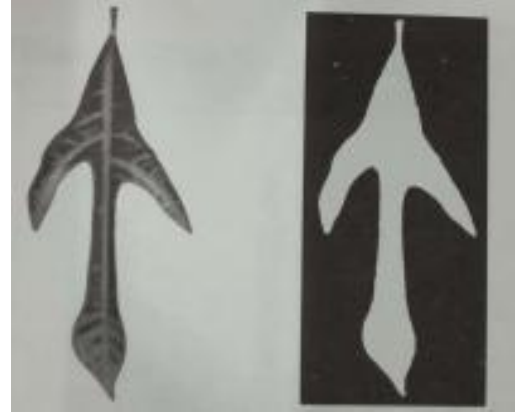

Gambar 2. Citra aras keabuan dan citra hasil konversi ke citra biner

\section{E. Citra Medis Magnetic Resonance Imaging (MRI)}

MRI merupakan salah satu alat kesehatan di bidang radiologi diagnostik yang menggunakan medan magnet untuk menghasilkan material penampang organ manusia. Beberapa keuntungan dari MRI adalah kemampuannya untuk membuat sayatan koronal, sagital dan aksial tanpa kontrol posisi pasien yang tidak semestinya, yang membuatnya sangat cocok untuk diagnosis jaringan lunak. Kualitas gambar MRI dapat memberikan gambar manusia yang terperinci dengan kontras yang berbeda, yang memungkinkan penilaian yang cermat terhadap anatomi dan patologi jaringan manusia [6], [7]. Gambar 3 menunjukkan peralatan MRI dan gambar MRI.
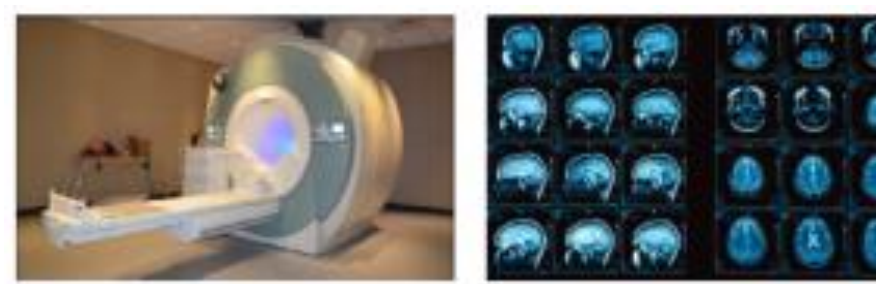

Gambar 3. Alat MRI dan Citra MRI

\section{F. Segmentasi Citra (Image Segmentation)}

Segmentasi citra merupakan suatu proses yang bertujuan untuk mendapatkan objek yang terdapat pada suatu citra atau membagi citra menjadi beberapa wilayah yang masing-masing memiliki sifat yang sama. Pada gambar yang hanya berisi satu objek, objek tersebut berbeda dengan latar belakangnya. Pada gambar yang berisi banyak objek, proses pengurutan semua objek tentunya lebih rumit. Gambar 4 menunjukkan pemisahan objek daun dari latar belakangnya.

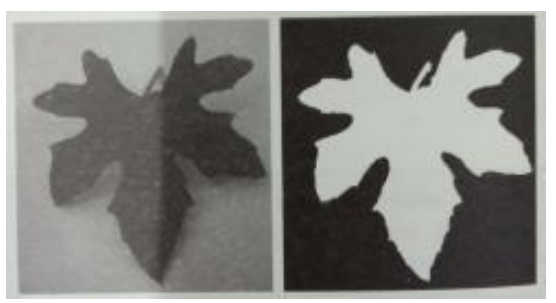

Gambar 4. Pemisahan objek daun terhadap latar belakang

\section{G. K-Means Clustering}

Algoritma K-Means mengelompokkan objek ke dalam K cluster. Metode ini menemukan pusat cluster dan batas cluster melalui proses iteratif. Kedekatan atau kemiripan suatu objek dengan pusat objek atau cluster lain dihitung menggunakan fungsi jarak. Secara umum, K-Means menggunakan jarak Euclidean untuk menghitung kemiripan. Prosedur untuk algoritma K-Means adalah sebagai berikut[8], [9]:

1. Inisialisasi $K$ pusat kluster adalah $z_{1}(1)$, $z_{2}(1), \ldots z_{k}(1)$. Pusat-pusat kluster ini biasanya dipilih secara sembarang dari sekumpulan data yang akan dikelompokkan.

2. Pada iterasi ke-k didistribusikan sampel data $\{\mathrm{x}\}$ diantara $\mathrm{K}$ domain kluster, dengan menggunakan hubungan sebagain berikut:

$$
\begin{aligned}
x \in S_{j}(k) \text { if } & || x-S_{j}(k) \mid \\
& <|| x-S_{i}(k) \|
\end{aligned}
$$

Untuk semua $\mathrm{i}=1,2, \ldots . . \mathrm{K}, \mathrm{i} \neq \mathrm{j}$, dengan $S_{j}(k)$ menyatakan himpunan sampel dengan pusat kluster adalah $z_{j}(k)$.

3. Dari hasil pada langkah 2 , hitung pusat-pusat kluster baru $z_{j}(k+1), \mathrm{j}=1,2, \ldots \mathrm{K}$, sehingga jumlah seluruh jarak dari semua titik dalam $S_{j}(k)$ ke pusat kluster baru minimal. Dengan kata lain, pusat kluster baru $z_{j}(k+1)$ dihitung sehingga unjuk kerja indeks:

$$
J_{j}=\sum_{x \in S_{j}(k)}\left\|x-z_{j}(k+1)\right\|^{2}, j=1,2, \ldots K
$$

$z_{j}(k+1)$ yang meminimalkan persamaan diatas adalah dengan menyederhanakan nilai rata-rata dari sampel pada $S_{j}(k)$. Maka dari itu, pusat kluster baru ditunjukkan oleh:

$$
z_{j}(k+1)=\frac{1}{N_{j}} \sum_{x \in s_{j}(k)} x, j=1,2, \ldots K
$$

Dengan $N_{j}$ menyatakan jumlah sampel da$\operatorname{lam} S_{j}(k)$.

4. Bila $z_{j}(k+1)=z_{j}(k)$ untuk $\mathrm{j}=1,2, \ldots \mathrm{K}$, maka algoritma telah konvergen dan proses berakhir. Bila tidak kembali ke langkah 2.

Gambar 5 menunjukkan ilustrasi proses pengelompokkan dari algoritma $k$-means. 


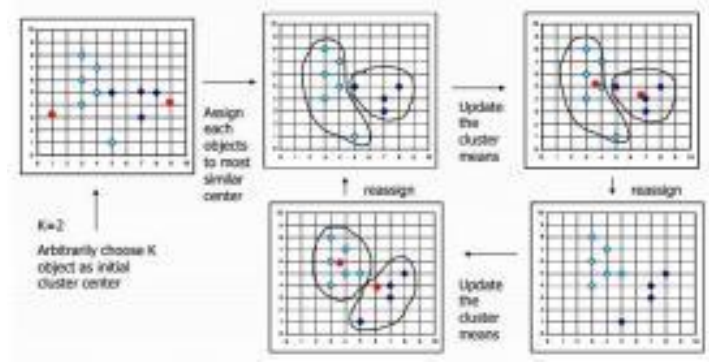

Gambar 5. Proses pengelompokkan algoritma $k$-means

\section{H. Fuzzy C Means Clustering}

Fuzzy C-Means (FCM) merupakan suatu teknik clustering data dimana keberadaan setiap titik data dalam cluster ditentukan oleh derajat keanggotaannya [8]. Dalam kondisi awal, pusat cluster masih tidak akurat. Setiap titik data memiliki tingkat keanggotaan untuk setiap cluster. Meningkatkan pusat cluster dan tingkat keanggotaan memindahkan setiap cluster ke tempat yang tepat. Iterasi ini didasarkan pada fungsi objektif yang meminimalkan jarak antara titik data tertentu dan pusat cluster, yang diboboti oleh afiliasi titik data ini.

Langkah-langkah untuk menggunakan metode Fuzzy C-Means adalah sebagai berikut [2], [10], [11]:

1. Menentukan Matriks $X$ yang merupakan data yang akan dicluster, berukuran $\mathrm{k} \mathrm{x} \mathrm{j}$, dengan $\mathrm{k}=$ jumlah data yang akan di-cluster dan $\mathrm{j}=$ jumlah variabel/atribut (kriteria).

$$
\left[\begin{array}{cccc}
X_{11} & X_{12} & \ldots & X_{1 j} \\
X_{21} & X_{22} & & X_{2 j} \\
\vdots & \vdots & \ddots & \vdots \\
X_{k 1} & X_{k 2} & \cdots & X_{k j}
\end{array}\right]
$$

2. Menentukan: a. Jumlah cluster yang akan dibentuk $(n>c \geq 2)$.

$\left(\mathrm{P}_{0}\right)$.

b. pembobot $(\mathrm{w}>1)$.

c. Maksimum iterasi (max n).

d. Kriteria penghentian/treshold $(\varepsilon=$ nilai positif yang sangat kecil).

e. Menentukan fungsi obyektif awal

3. Membentuk matriks partisi awal U (derajat keanggotaan dalam cluster) dengan ukuran k x i; matriks partisi biasanya dibuat acak, dengan $\mathrm{k}=$ jumlah data yang akan di-cluster dan $\mathrm{i}=$ jumlah cluster

$$
U=\left[\begin{array}{cccc}
11 " & 1 & 12 & { }^{2} \\
\mu_{21}\left(x_{1}\right) & \mu_{22}\left(x_{2}\right) & \cdots & \mu_{2 n}^{n}\left(x_{n}\right) \\
\vdots & & & \vdots \\
\mu_{c 1}\left(x_{1}\right) & \mu_{c 2}\left(x_{2}\right) & \cdots & \mu_{c n}\left(x_{n}\right)
\end{array} \mid\right.
$$

4. Komputasi titik tengah cluster-cluster tersebut. Hitung pusat cluster $\mathrm{V}$ untuk setiap cluster

$$
V_{i j}=\frac{\sum_{k=1}^{n}\left(\mu_{i k}\right)^{w} X_{k j}}{\sum_{k=1}^{n}\left(\mu_{i k}\right)^{2}}
$$

5. Pindahkan titik tengah cluster ke titik tengah baru yang didapat dari hasil komputasi.

$$
\begin{gathered}
\mu_{i k}=\left[\sum_{i=1}^{c}\left(\frac{d_{i k}}{d_{j k}}\right)^{2}\right]^{-1} \\
d_{i k}=d\left(x_{k}-v_{i}\right)=\left[\sum_{j=1}^{m}\left(x_{k j}-v_{i j}\right)\right]^{2}
\end{gathered}
$$

6. Ulangi kedua langkah terakhir sampai kriteria konvergensi telah terpenuhi, atau sampai titik-titik tengah tersebut tidak berubah keadaannya.

7. Setelah kriteria tersebut terpenuhi, maka akan didapat derajat keanggotaan dari masing-masing data. Tentukan kriteria penghentian iterasi berdasarkan perubahan matriks partisi pada iterasi saat ini dan iterasi sebelumnya.

$$
\triangle=|| U^{t}-U^{t-1}|| \triangle<\varepsilon
$$

8. Klasifikasikan data tersebut kedalam cluster-cluster yang telah ditentukan.

\section{Parameter Pengukuran Uji Performansi}

Uji kualitas citra hasil segmentasi dapat diukur secara kuantitatif melalui uji performansi dengan menggunakan parameter sebagai berikut:

a. MSE (Mean Square Error), yang merupakan sigma dari jumlah kesalahan antara citra tersegmentasi dengan citra asli. MSE dapat dihitung menggunakan persamaan berikut:

MSE $=\frac{1}{\operatorname{MxN}} \sum_{i=1}^{M} \sum_{j=1}^{N}\left(\left(f_{a}(i, j)-f_{b}(i, j)\right)^{2}\right.$

$\mathrm{M}$ dan $\mathrm{N}$ adalah ukuran panjang dan lebar citra. $\mathrm{f}_{\mathrm{a}}(\mathrm{i}, \mathrm{j})$

$=$ intensitas citra di titik $(\mathrm{i}, \mathrm{j})$ citra asli

$\mathrm{f}_{\mathrm{b}}(\mathrm{i}, \mathrm{j})$

$=$ intensitas citra di titik $(i, j)$ citra segmentasi Semakin kecil nilai MSE maka semakin baik kualitas citra hasil segmentasinya.

b. PSNR (Peak Signal to Noise Ratio). PSNR dapat dihitung menggunakan persamaan berikut:

$$
P S N R=20 \log _{10} \frac{255}{M S E}
$$

Semakin tinggi nilai PSNR maka semakin dekat segmentasi citra dengan citra aslinya. Sebaliknya semakin kecil nilai PSNR maka semakin buruk kualitas citra hasil segmentasi.

c. Variasi informasi (VOI)

Parameter Information Fluctuation (VOI) mengukur jumlah informasi yang hilang dan diperoleh antara dua cluster. Oleh karena itu, ini adalah ukuran kasar seberapa baik satu cluster dapat menjelaskan cluster lainnya.

d. Kesalahan Konsistensi Global (GCE)

Parameter Global Consistency Error (GCE) adalah segmentasi konsistensi berbasis 
area yang mengukur konsistensi antara segmentasi gambar dengan ukuran partikel yang berbeda.

Global Consistency Error (GCE) mengukur kesalahan segmentasi dengan dua segmen S1 dan S2 sebagai input dan output nilai aktual dalam rentang [0:: 1]. Di sini, nol berarti tidak ada kesalahan [2], [10], [11.

\section{Metode Penelitian}

Citra yang digunakan adalah Citra MRI Otak (Brain MRI) dan citra MRI payudara (Breast MRI) baik kondisi normal maupun yang mengalami gangguan (lesi). Citra input yang sudah mengalami preprocessing berupa kompresi dengan tujuan mengurangi penggunaan memory. Citra input ini kemudian di segmentasi menggunakan metode $K$-Means dan Fuzzy $C$ Means. Hasil uji performansi kedua metode kemudian dikomparasikan hasilnya.

Perangkat yang digunakan dalam penelitian ini adalah laptop dengan spesifikasi sebagai berikut: Sistem komputer: Core 2 duo T5870, Sistem Operasi: Microsoft Windows 7, RAM: RAM 2 GB dan software Matlab R2013A.

Ketiga ekstensi tersebut dibandingkan menggunakan parameter Variation of Information (VOI), Global Consistency Error (GCE), MSE (Mean Square Error) dan PSNR (Peak Signal to Noise Ratio). Di bawah ini adalah diagram blok dan cuplikan kode sumber dari desain pengujian kinerja segmentasi menggunakan Matlab. Diagram blok untuk menghitung Global Consistency Error (GCE) dengan Matlab

1. Blok diagram menghitung Variation of Information

(VOI) menggunakan Matlab

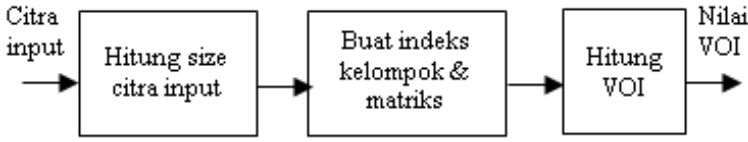

2. Blok diagram menghitung MSE (Mean Square Error) \& PSNR (Peak Signal to Noise Ratio) menggunakan Matlab

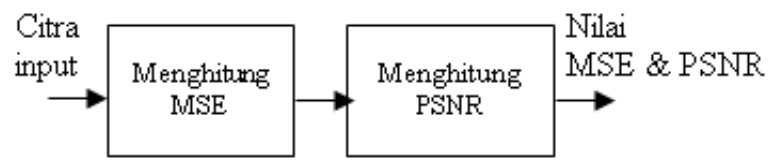

\section{HASIL DAN PEMBAHASAN}

Bagian ini menyajikan hasil implementasi yang telah dilakukan. Tes kinerja segmentasi dilakukan pada 10 gambar MRI terkompresi (otak dan payudara), baik dalam kondisi normal maupun dengan lesi (gangguan). Gambar yang digunakan adalah gambar dengan ekstensi JPG, PNG dan BMP. Tabel 2 menunjukkan deskripsi citra masukan dan citra tersegmentasi.
Tabel 2. Citra Input dan Citra Hasil Segmentasi

\begin{tabular}{|c|c|c|c|c|}
\hline & \multirow{2}{*}{$\begin{array}{c}\text { Citra Asli } \\
\text { (Kompresi) }\end{array}$} & \multirow{2}{*}{$\begin{array}{c}\text { Deskripsi Citra } \\
\text { Input } \\
\end{array}$} & \multicolumn{2}{|c|}{ Citra Segmentasi } \\
\hline & & & K-Means & Fuzzy C Means \\
\hline 1 & & $\begin{array}{l}\text { JPG, in = } 149 \mathrm{~KB}, \\
\text { Out = } 106,3 \mathrm{~KB}, \\
\text { MRI (Otak) } \\
\text { terdapat lesi }\end{array}$ & & \\
\hline 2 & & $\begin{array}{l}\text { PNG, in }=407 \mathrm{~KB} \text {, } \\
\text { Mut }=257,6 \mathrm{~KB} \text {, (Otak) } \\
\text { MRI } \\
\text { terdapat lesi }\end{array}$ & & \\
\hline 3 & & $\begin{array}{l}\text { JPG, in }=199 \mathrm{~KB} \text {, } \\
\text { Out }=118,3 \mathrm{~KB} \text {, } \\
\text { MRI (Otak) } \\
\text { terdapat lesi }\end{array}$ & & \\
\hline 4 & & $\begin{array}{l}\text { JPG, in = } 121 \mathrm{~KB}, \\
\text { Out }=94,9 \mathrm{~KB}, \\
\text { MRI } \\
\text { terdapat lesi }\end{array}$ & & \\
\hline 5 & & $\begin{array}{l}\text { JPG, in }=294 \mathrm{~KB} \text {, } \\
\text { Out }=185,1 \mathrm{~KB}, \\
\text { MRI (Otak) } \\
\text { kondisi normal }\end{array}$ & & \\
\hline 6 & & $\begin{array}{l}\mathrm{BMP}, \text { in }=755 \mathrm{~KB} \text {, } \\
\text { Out }=754 \mathrm{~KB} \text {, } \\
\text { MRI (Otak) } \\
\text { terdapat lesi }\end{array}$ & & \\
\hline 7 & & $\begin{array}{l}\text { BMP, in = } 887 \mathrm{~KB} \text {, } \\
\text { Out = } 885 \mathrm{~KB} \text {, } \\
\text { MRI (Payudara) } \\
\text { terdapat lesi }\end{array}$ & & \\
\hline 8 & & $\begin{array}{l}\text { PNG, in }=389 \mathrm{~KB} \text {, } \\
\text { Out }=235 \mathrm{~KB} \text {, } \\
\text { MRI (Payudara) } \\
\text { terdapat lesi }\end{array}$ & & \\
\hline 9 & & $\begin{array}{l}\text { JPG, in = } 141 \mathrm{~KB} \text {, } \\
\text { Out = } 63,7 \mathrm{~KB} \text {, } \\
\text { MRI (Payudara) } \\
\text { kondisi normal }\end{array}$ & & \\
\hline 10 & & $\begin{array}{l}\text { JPG, in }=153 \mathrm{~KB} \text {, } \\
\text { Out = } 35,1 \mathrm{~KB} \text {, } \\
\text { MRI (Payudara) } \\
\text { kondisi normal }\end{array}$ & & \\
\hline
\end{tabular}

Tabel 3. Hasil uji performansi metode K-Means

\begin{tabular}{ccccccc}
\hline \multirow{2}{*}{ No } & \multirow{2}{*}{ Citra Input } & \multicolumn{5}{c}{$\boldsymbol{K}$-Means } \\
\cline { 3 - 7 } & VOI & GCE & MSE & PSNR & Waktu \\
\hline 1 & Citra 1 & 0,9306 & 0,5040 & 6,2900 & 5,2402 & 0,16436 \\
\hline 2 & Citra 2 & 0,9586 & 0,5808 & 4,9000 & 8,1813 & 0,47173 \\
\hline 3 & Citra 3 & 0,8484 & 0,5546 & 6,5202 & 5,0957 & 0,16183 \\
\hline 4 & Citra 4 & 0,8875 & 0,5275 & 6,7361 & 8,3371 & 0,26986 \\
\hline 5 & Citra 5 & 0,9306 & 0,5040 & 6,2900 & 5,2402 & 0,10245 \\
\hline 6 & Citra 6 & 0,9395 & 0,5271 & 5,1262 & 10,9970 & 0,89456 \\
\hline 7 & Citra 7 & 0,9695 & 0,5871 & 5,1662 & 10,9273 & 0,56781 \\
\hline 8 & Citra 8 & 0,9586 & 0,5808 & 4,9000 & 8,1813 & 0,51872 \\
\hline 9 & Citra 9 & 0,8484 & 0,5546 & 6,5202 & 5,0957 & 0,16185 \\
\hline 10 & Citra 10 & 0,8549 & 0,5724 & 6,2491 & 2,3535 & 0,26986 \\
\hline & & & & & &
\end{tabular}

Pada Tabel 3 menunjukkan hasil uji performansi VOI, GCE, MSE, PSNR, serta waktu yang dibutuhkan untuk proses segmentasi dari ketiga ekstensi citra menggunakan metode $K$-Means. 
Tabel 4. Hasil uji performansi metode Fuzzy C Means

\begin{tabular}{ccccccc}
\hline \multirow{2}{*}{ No } & \multirow{2}{*}{ Citra Input } & \multicolumn{5}{c}{ Fuzzy CMeans } \\
\cline { 3 - 7 } & & VOI & GCE & MSE & PSNR & Waktu \\
\hline 1 & Citra 1 & 0,9631 & 0,6407 & 6,7615 & 12,5681 & 2,09011 \\
\hline 2 & Citra 2 & 0,9631 & 0,6047 & 6,4928 & 12,5688 & 2,10751 \\
\hline 3 & Citra 3 & 0,8625 & 0,6101 & 6,6290 & 16,1224 & 3,50487 \\
\hline 4 & Citra 4 & 0,9065 & 0,6992 & 6,5883 & 5,5082 & 2,27159 \\
\hline 5 & Citra 5 & 0,9631 & 0,6407 & 6,7615 & 12,5681 & 3,65352 \\
\hline 6 & Citra 6 & 0,9631 & 0,6047 & 6,3140 & 12,5688 & 2,12312 \\
\hline 7 & Citra 7 & 0,9631 & 0,6047 & 6,3140 & 12,5688 & 3,65102 \\
\hline 8 & Citra 8 & 0,9631 & 0,6047 & 6,4928 & 12,5688 & 3,51702 \\
\hline 9 & Citra 9 & 0,8625 & 0,6101 & 6,6290 & 16,1224 & 2,27159 \\
\hline 10 & Citra 10 & 0,9032 & 0,6885 & 6,4584 & 10,9094 & 2,27159 \\
\hline & & & & & &
\end{tabular}

Pada Tabel 4 menunjukkan hasil uji performansi VOI, GCE, MSE, PSNR, serta waktu yang dibutuhkan untuk proses segmentasi dari ketiga ekstensi citra menggunakan metode Fuzzy C Means.

Tabel 5. Rata-Rata Perhitungan Uji Performansi K-Means

\begin{tabular}{ccccccc}
\hline No & $\begin{array}{c}\text { Ekstensi } \\
\text { Citra }\end{array}$ & vOI & GCE & MSE & PSNR & Waktu \\
\hline 1 & JPG & 0.8834 & 0.5362 & 6.4343 & 5.2271 & 0.1884 \\
\hline 2 & PNG & 0.9586 & 0.5808 & 4.900 & 8.1813 & 0.4952 \\
\hline 3 & BMP & 0.9545 & 0.5571 & 5.1462 & 10.9621 & 0.7312 \\
\hline
\end{tabular}

Pada Tabel 5 menunjukkan rata-rata hasil perhitungan analisa uji performansi VOI, GCE, MSE, PSNR, serta waktu yang dibutuhkan untuk proses segmentasi dari ketiga ekstensi citra menggunakan metode $K$-Means.

Tabel 6. Rata-Rata Perhitungan Uji Performansi Fuzzy C Means

\begin{tabular}{ccccccc}
\hline No & $\begin{array}{c}\text { Ekstensi } \\
\text { Citra }\end{array}$ & vOI & GCE & MSE & PSNR & Waktu \\
\hline 1 & JPG & 0.9102 & 0.6482 & 6.6379 & 12.2998 & 2.6772 \\
\hline 2 & PNG & 0.9631 & 0.6047 & 6.4928 & 12.5688 & 2.8123 \\
\hline 3 & BMP & 0.9631 & 0.6047 & 6.3140 & 12.5688 & 2.8871 \\
\hline
\end{tabular}

Pada Tabel 6 menunjukkan rata-rata hasil perhitungan analisa uji performansi VOI, GCE, MSE, PSNR, serta waktu yang dibutuhkan untuk proses segmentasi dari ketiga ekstensi citra menggunakan metode Fuzzy $C$ Means.

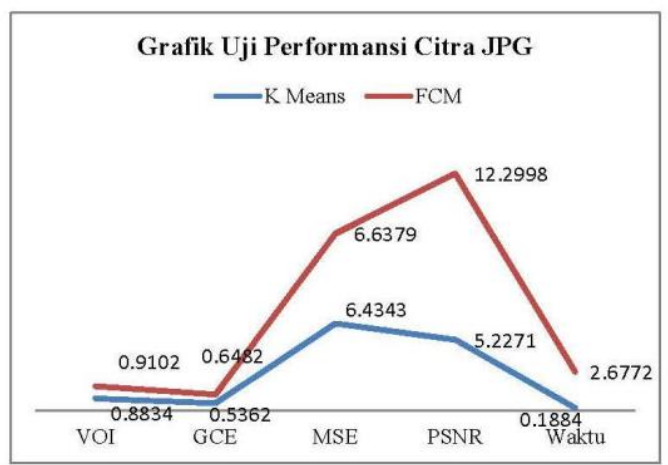

Gambar 6. Uji Performansi Citra JPG

Pada Gambar 6 menunjukkan grafik perbandingan uji performansi metode $K$-Means dan FCM untuk citra ekstensi JPG. Dari grafik uji performansi citra JPG, dapat dianalisa sebagai berikut:
1. Parameter VOI mengukur jumlah kehilangan informasi dalam proses segmentasi. Semakin rendah nilai VOI menunjukkan semakin sedikit kehilangan informasi (memiliki nilai kesamaan yang lebih besar). Nilai VOI pada metode $K$ Means sebesar 0,8834 sedangkan untuk metode FCM nilai VOI 0,9102. Ini menandakan bahwa metode $K$-Means lebih sedikit kehilangan informasi dalam proses segmentasi dibandingkan metode FCM.

2. Parameter GCE mengukur tingkat kesalahan dalam proses segmentasi. Semakin mendekati nol menandakan tidak ada kesalahan dalam proses segmentasi. Nilai GCE pada metode $K$ Means sebesar 0,5362 sedangkan untuk metode FCM nilai GCE 0,6482. Ini menandakan bahwa metode $K$-Means lebih sedikit terjadi kesalahan dalam proses segmentasi dibandingkan metode FCM.

3. Parameter MSE mengukur sigma dari jumlah error antara citra hasil segmentasi dengan citra asli. Semakin kecil nilai MSE, semakin bagus hasil segmentasi citra. Nilai MSE pada metode K-Means sebesar 6,4343 sedangkan untuk metode FCM nilai MSE 6,6379. Ini menandakan bahwa metode $K$-Means memiliki kualitas lebih bagus dalam proses segmentasi dibandingkan metode FCM.

4. Parameter PSNR merupakan kebalikan dari MSE, Semakin tinggi nilai PSNR, semakin dekat citra tersegmentasi dengan citra aslinya; namun, semakin rendah nilai PSNR, semakin buruk kualitas gambar tersegmentasi. Nilai PSNR metode K-Means sebesar 5,2271 sedangkan metode FCM nilai PSNR 12,2998. Ini menandakan metode FCM memiliki kualitas segmentasi citra yang mendekati citra asli.

5. Parameter waktu segmentasi mengukur waktu yang dibutuhkan metode dalam proses segmentasi. Metode $K$-Means membutuhkan waktu 0,1884 detik sedangkan metode FCM membutuhkan waktu 2,6672 detik. Ini menandakan metode $K$-Means lebih cepat dalam proses segmentasi citra dibandingkan metode FCM.

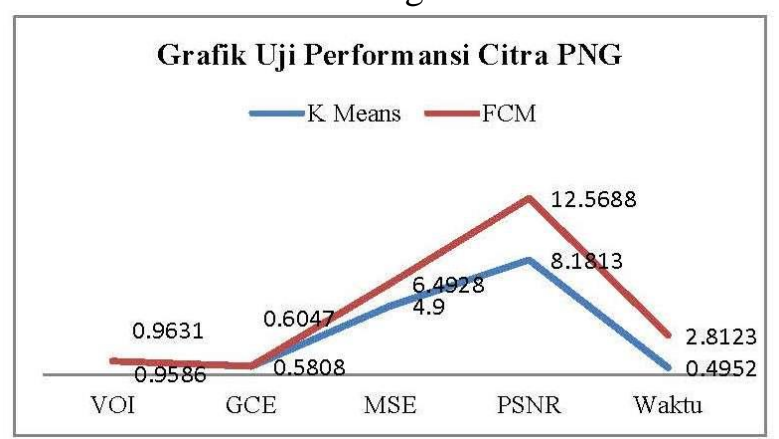

Gambar 7. Uji Performansi Citra PNG 
Pada Gambar 7 menunjukkan grafik perbandingan uji performansi metode $K$-Means dan FCM untuk citra ekstensi PNG. Dari grafik uji performansi citra PNG, dapat dianalisa sebagai berikut:

1. Parameter VOI mengukur jumlah kehilangan informasi dalam proses segmentasi. Semakin rendah nilai VOI menunjukkan semakin sedikit kehilangan informasi (memiliki nilai kesamaan yang lebih besar). Nilai VOI pada metode $K$ Means sebesar 0,9586 sedangkan untuk metode FCM nilai VOI 0,9631. Ini menandakan bahwa metode $K$-Means lebih sedikit kehilangan informasi dalam proses segmentasi dibandingkan metode FCM.

2. Parameter GCE mengukur tingkat kesalahan dalam proses segmentasi. Semakin mendekati nol menandakan tidak ada kesalahan dalam proses segmentasi. Nilai GCE pada metode $K$ Means sebesar 0,5808 sedangkan untuk metode FCM nilai GCE 0,6047. Ini menandakan bahwa metode $K$-Means lebih sedikit terjadi kesalahan dalam proses segmentasi dibandingkan metode FCM.

3. Parameter MSE mengukur sigma dari jumlah error antara citra hasil segmentasi dengan citra asli. Semakin kecil nilai MSE, semakin bagus hasil segmentasi citra. Nilai MSE pada metode K-Means sebesar 4,900 sedangkan untuk metode FCM nilai MSE 6,4928. Ini menandakan bahwa metode $K$-Means memiliki kualitas lebih bagus dalam proses segmentasi dibandingkan metode FCM.

4. Parameter PSNR berlawanan dengan MSE, semakin tinggi nilai PSNR maka semakin dekat citra tersegmentasi dengan citra aslinya, sebaliknya semakin kecil nilai PSNR maka kualitas citra tersegmentasi semakin buruk. Nilai PSNR metode K-Means sebesar 8.1813, dan nilai PSNR metode PSNR adalah 12.5688. Hal ini menunjukkan bahwa kualitas segmentasi citra metode FCM mendekati citra asli.

5. Parameter waktu segmentasi mengukur waktu yang dibutuhkan metode dalam proses segmentasi. Metode K-Means membutuhkan waktu 0,4952 detik sedangkan metode FCM membutuhkan waktu 2,8123 detik. Ini menandakan metode $K$-Means lebih cepat dalam proses segmentasi citra dibandingkan metode FCM.

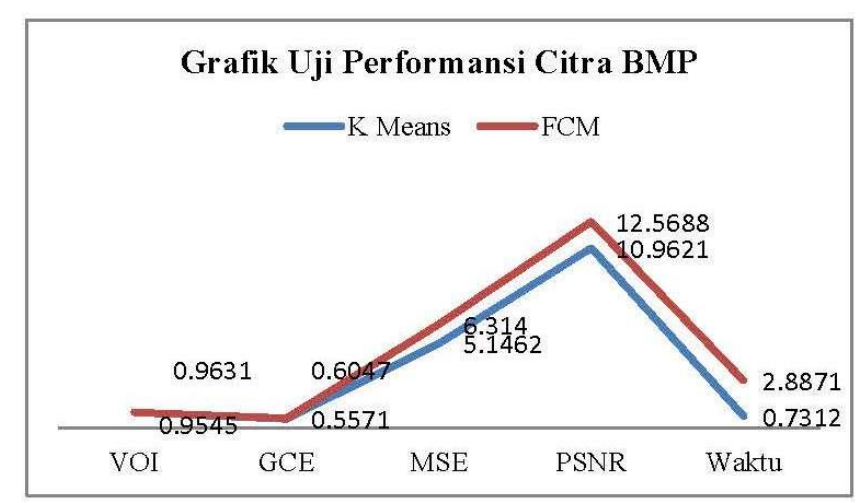

Gambar 8. Uji Performansi Citra BMP

Pada Gambar 8 menunjukkan grafik perbandingan uji performansi metode $K$-Means dan FCM untuk citra ekstensi BMP. Dari grafik uji performansi citra BMP, dapat dianalisa sebagai berikut:

1. Parameter VOI mengukur jumlah kehilangan informasi dalam proses segmentasi. Semakin rendah nilai VOI menunjukkan semakin sedikit kehilangan informasi (memiliki nilai kesamaan yang lebih besar). Nilai VOI pada metode $K$ Means sebesar 0,9545 sedangkan untuk metode FCM nilai VOI 0,9631. Ini menandakan bahwa metode $K$-Means lebih sedikit kehilangan informasi dalam proses segmentasi dibandingkan metode FCM.

2. Parameter GCE mengukur tingkat kesalahan dalam proses segmentasi. Semakin mendekati nol menandakan tidak ada kesalahan dalam proses segmentasi. Nilai GCE pada metode $K$ Means sebesar 0,5571 sedangkan untuk metode FCM nilai GCE 0,6047. Ini menandakan bahwa metode $K$-Means lebih sedikit terjadi kesalahan dalam proses segmentasi dibandingkan metode FCM.

3. Parameter MSE mengukur sigma dari jumlah error antara citra hasil segmentasi dengan citra asli. Semakin kecil nilai MSE, semakin bagus hasil segmentasi citra. Nilai MSE pada metode $K$-Means sebesar 5,1462 sedangkan untuk metode FCM nilai MSE 6,3140. Ini menandakan bahwa metode $K$-Means memiliki kualitas lebih bagus dalam proses segmentasi dibandingkan metode FCM.

4. Parameter PSNR berlawanan dengan MSE, semakin tinggi nilai PSNR maka semakin dekat citra tersegmentasi dengan citra aslinya, sebaliknya semakin kecil nilai PSNR maka kualitas citra tersegmentasi semakin buruk. Nilai PSNR metode K-Means sebesar 10.9621, dan nilai PSNR metode FCM sebesar 12.5688. Hal ini menunjukkan bahwa kualitas segmentasi citra metode FCM mendekati citra asli.

5. Parameter waktu segmentasi mengukur waktu yang dibutuhkan metode dalam proses segmentasi. Metode $\mathrm{K}$-Means membutuhkan waktu 0,7312 detik sedangkan metode FCM membutuhkan waktu 2,8871 detik. Ini menandakan 
metode $K$-Means lebih cepat dalam proses segmentasi citra dibandingkan metode FCM.

\section{KESIMPUAN}

Berdasarkan hasil penelitian dan pembahasan dapat disimpulkan bahwa metode $K$-Means dan metode Fuzzy C Means (FCM) dapat melakukan proses segmentasi citra dengan baik.

Secara visual metode K-Means dan metode Fuzzy $C$ Means (FCM) dapat membedakan daerah yang normal dan daerah yang mengalami lesi (gangguan) baik pada citra MRI otak maupun pada citra MRI payudara. Terlihat batasan yang tegas antara daerah normal maupun daerah lesi (gangguan).

Bedasarkan hasil uji performansi kedua metode $K$ Means dan Fuzzy C Means (FCM), parameter VOI, GCE, MSE menunjukkan bahwa kulitas hasil segmentasi metode $K$-Means lebih bagus dibandingkan metode Fuzzy C Means (FCM). Untuk parameter PSNR menunjukkan hasil segmentasi metode Fuzzy C Means (FCM) lebih bagus dibandingkan metode $K$-Means. Sedangkan untuk waktu segmentasi, metode $K$-Means memerlukan waktu yang lbih singkat dalam proses segmentasi dibandingkan metode Fuzzy C Means (FCM).

\section{DAFTAR PUSTaKa}

[1] Nurhasanah, "Segementasi Jaringan Otak Putih, Jaringan Otak Abu-Abu, Dan Cairan Otak Dari Citra MRI Menggunakan Teknik K-Means Clustering," $J$. Apl. Fiska, vol. 7, no. 2, pp. 90-95, 2011.

[2] B. R. Jipkate and V. V. Gohokar, "A Comparative Analysis of Fuzzy C-Means Clustering and K Means Clustering Algorithms," Int. J. Comput. Eng. Res., vol. 2, pp. 737-739, 2012.

[3] A. S. B. Samma and R. A. Salam, Adaptation of $K$ Means Algorithm for Image Segmentation. 2009.

[4] P. Panwar, G. Gopal, and R. Kumar, "Image Segmentation using K-means clustering and Thresholding," Int. Res. J. Eng. Technol., vol. 03, no. 05, pp. 1787-1793, 2016.

[5] T. Sutoyo, E. Mulyanto, O. D. N. V. Suhartono, and Wijanarto, Teori Pengolahan Citra Digital. Yogyakarta: ANDI, 2009.

[6] I. W. A. W. K and A. K, "Penerapan Algoritma KMeans pada Kompresi Adaptif Citra Medis MRI," INFORMATIKA, vol. 11, no. 2, pp. 139-151, 2015.

[7] R. S. Kabade and M. S. Gaikwad, "Segmentation of Brain Tumour and Its Area Calculation in Brain MR Images using K-Mean Clustering and Fuzzy C-Mean Algorithm," Int. J. Comput. Sci. Eng. Technol., vol. 4, pp. 524-531, 2013.

[8] S. J. Saida, L. Srinivas, and R. Sivaram, “An Efficient K-Means and C-Means Clustering Algorithm for Image Segmentation," Int. J. Sci. Appl. Inf. Technol., vol. 1, no. 5, pp. 84-87, 2012.

[9] A. Bala and A. K. Sharma, "Color Image Segmentation using K-Means Clustering and Morphological Edge Detection Algorithm," Int. J. Latest Trends Eng. Technol., pp. 48-55, 2016.

[10] P. Fauzdar and S. Kindri, "Comparitive Analysis Of
K Means And Fuzzy C Means Algorithm," Int. J. Eng. Res. Technol., vol. 2, no. 6, pp. 2088-2095, 2013.

[11] D. A. Masatu, I. Soesanti, and H. A. Nugroho, "Penerapan Algoritma Kompresi JPEG dan Metode Fuzzy C Means pada Kompresi Citra Berbasis Entropi," J. Penelit. Tek. Elektro dan Teknol. Inf., vol. 1, no. 1, pp. 7-11, 2014.

[12] Jiawei Han, Micheline Kamber, Jian Pei, Data Mining Concept and Techniques Third Edition, Morgan Kaufmann, 2012.

[13] Jiawei Han, Micheline Kamber, Data Mining: Concepts and Techniques Second Edition, Diane Cerra Publisher, 2006.

[14] M. North, Data Mining for the Masses, 2012.

[15] S. panda, "Color Image Segmentation Using K-means Clustering and Thresholding Technique," IJESC, pp. 1132-1136, 2015. 